\title{
Mutational analysis of the $B R A F$ gene in colorectal mucinous carcinoma in association with histological configuration
}

\author{
NAOTO YOSHITAKE ${ }^{1,2}$, SHIGEHIKO FUJII ${ }^{1,3}$, KENICHIROH MUKAWA ${ }^{1,2}$, KEIICHI TOMINAGA $^{1,2}$, \\ HIROKAZU FUKUI ${ }^{1}$, KAZUHITO ICHIKAWA ${ }^{1}$, SHIGEKI TOMITA ${ }^{1}$, YUKO ONO ${ }^{1}$, \\ YASUO IMAI $^{1}$, AKIRA TERANO $^{2}$, HIDEYUKI HIRAISHI $^{2}$ and TAKAHIRO FUJIMORI ${ }^{1}$
}

Departments of ${ }^{1}$ Surgical and Molecular Pathology, and ${ }^{2}$ Gastroenterology, Dokkyo University School of Medicine, Tochigi;

${ }^{3}$ Department of Gastroenterology and Hepatology, Kyoto University Graduate School of Medicine, Kyoto, Japan

Received September 4, 2006; Accepted October 12, 2006

\begin{abstract}
Genetic alterations and their association with clinicopathological features in colorectal mucinous carcinoma (MC) remain unknown. In particular, little is known about the mutational status of the $B R A F$ gene, which is activated by oncogenic Ras. This study aimed to evaluate the status of $B R A F$ together with K-ras, p53 and mismatch-repair deficiency to clarify their association with tumorigenesis of colorectal MC. $B R A F$ and $\mathrm{K}$-ras mutations were determined in 43 colorectal MCs by direct sequencing. p53 alteration was investigated immunohistochemically. The status of mismatch-repair deficiency was assessed by microsatellite analyses and immunohistochemistry for hMLH1. We also examined the association between these molecular alterations and clinicopathological features including histological configuration. $B R A F$ mutation was detected in $4(9.3 \%)$ tumors and was located at codon 599 of exon 15 in all cases. K-ras mutation was detected in 13 tumors (30.2\%). No BRAF and K-ras mutations were identified simultaneously in the same tumor. The incidence of mismatch-repair deficiency tended to be higher in MC with $B R A F$ mutation than without. In terms of histological configuration, we classified the cases according to growth type by tumor edge morphology. All MCs with $B R A F$ mutation and 9 of 13 MCs (69.2\%) with K-ras mutation were classified as polypoid type. BRAF and K-ras mutation did not affect patient prognosis, but non polypoid type was significantly more aggressive than polypoid type. Our findings indicate that $B R A F$ mutation plays an important role in the tumorigenesis of colorectal MC and in tumor edge morphology, similar to K-ras mutation.
\end{abstract}

Correspondence to: Dr Shigehiko Fujii, Department of Surgical and Molecular Pathology, Dokkyo University School of Medicine, 880 Kitakobayashi, Mibu, Shimotsuga, Tochigi 321-0293, Japan E-mail: sfujii@kuhp.kyoto-u.ac.jp

Key words: colorectal mucinous carcinoma, $B R A F, \mathrm{~K}-\mathrm{ras}$, growth type

\section{Introduction}

Colorectal mucinous carcinoma (MC), one of the subsets of colorectal adenocarcinomas, is diagnosed when extracellular mucin constituted more than $50 \%$ of the carcinoma volume, according to the World Health Organization (WHO) definition (1). MC represents $5-15 \%$ of colorectal carcinomas $(2,3)$. Although the clinicopathologic significance of colorectal MC has been recognized for a long time, its biological features are still under investigation and discussion.

Colorectal carcinoma has a multi-step process characterized by a sequence of genetic alterations in cell growth regulatory genes (4). Mutational activation of the RAS gene, in particular the K-ras oncogene, is an early event and is considered to play a role in the progression of size and grade of atypia $(5,6) . R A S$ is part of the Ras/Raf/MEK/MAP kinase cascade, which is an essential component of intracellular signaling from activated cell surface receptors to transcription factors in the cell nucleus (7). Recently, activating mutation of $B R A F$, a member of the $R A F$ gene family, has been found in malignant melanomas and in a wide range of human carcinomas. In colorectal carcinoma, although the incidence of $B R A F$ mutation is reportedly approximately $10 \%$, no study has focused on this mutation in MC (8). More recent data indicated that $B R A F$ mutation is associated with a high frequency of microsatellite instability (MSI) and inactivation of the mismatch-repair (MMR) gene in colorectal carcinoma.

In the present study, we analyzed the status of $B R A F$ together with K-ras, p53, hMLH1 and MSI to clarify their association with tumorigenesis in colorectal MC. Additionally, we examined the association between these molecular alterations and clinicopathological features.

\section{Materials and methods}

Patients and tissue samples. We obtained 43 samples of colorectal MC by surgical resection from 43 patients at Dokkyo University School of Medicine Hospital between 1988 and 2005. Patients with familial adenomatous polyposis, hereditary nonpolyposis colorectal cancer or inflammatory bowel disease were excluded from this study. The study was performed with the approval of Dokkyo University Surgical 

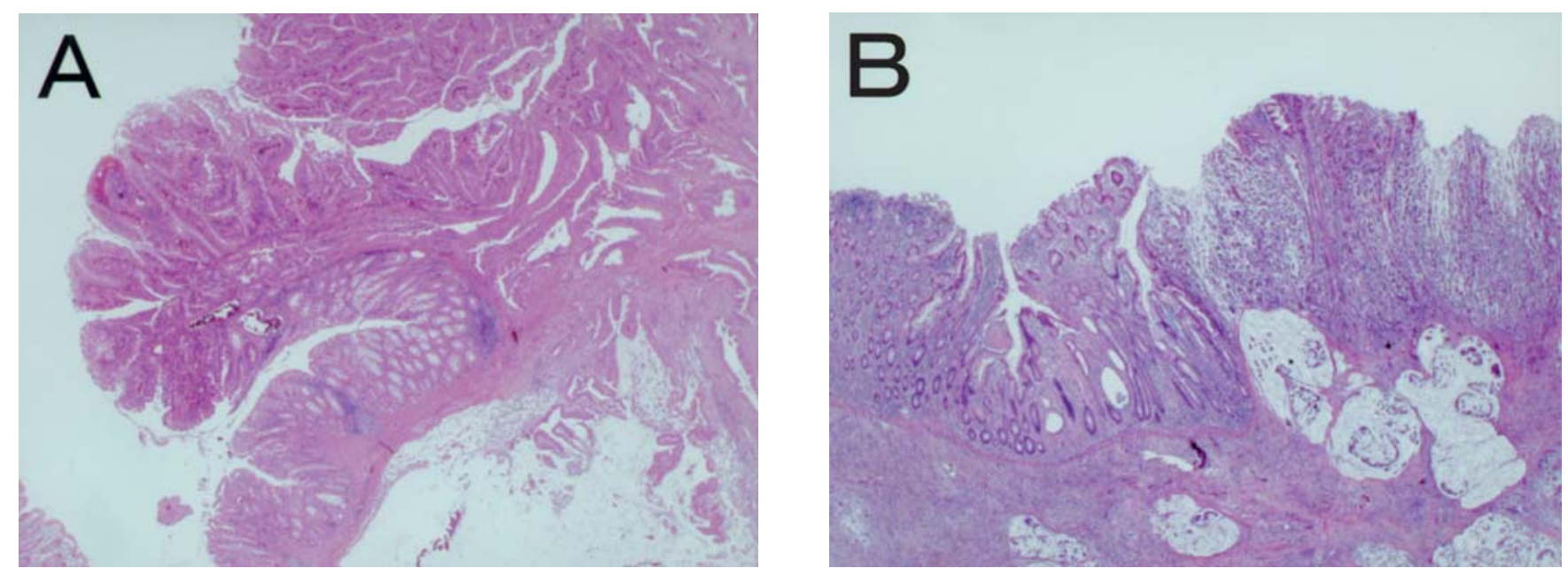

Figure 1. Tumor edge morphology of colorectal MC. (A) Polypoid-type tumor growing above the level of the normal mucosa at the tumor margin. (B) Nonpolypoid-type tumor does not grow above the level of the normal mucosa at the tumor margin (staining by hematoxylin and eosin, magnification x2).
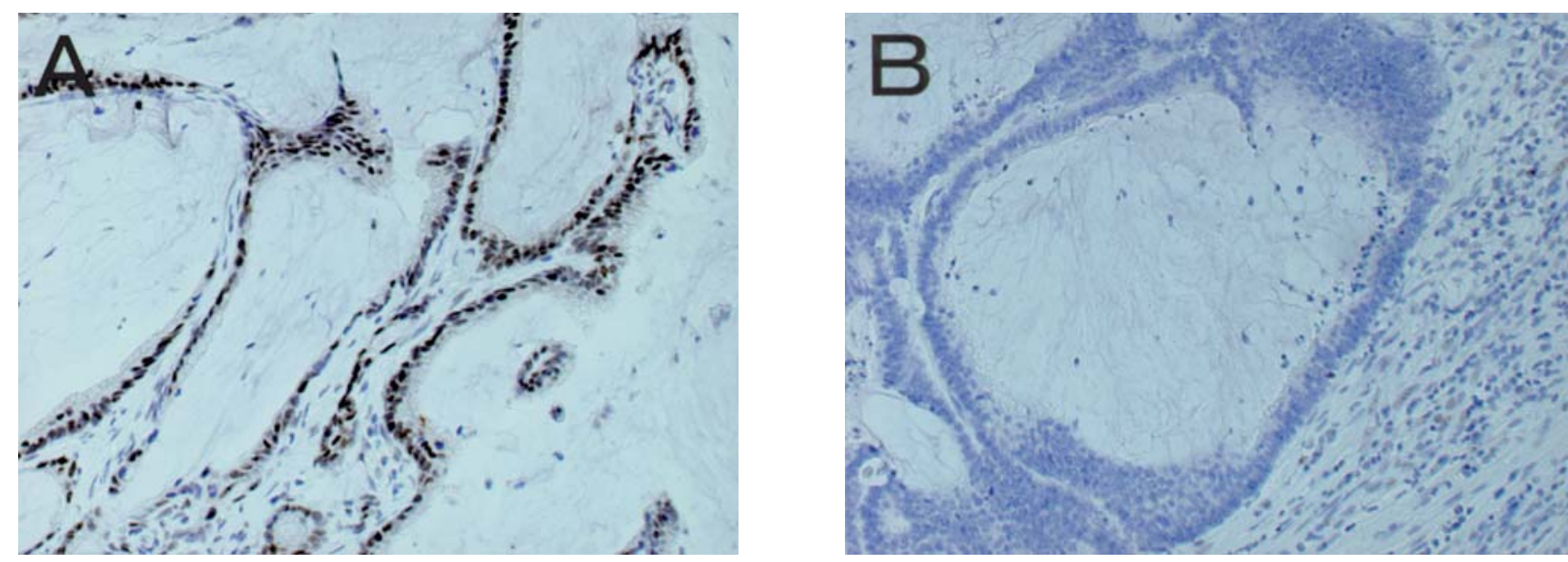

Figure 2. Immunohistochemical staining of hMLH1. (A) hMLH1-positive colorectal MC. Immunoreactivity of hMLH1 in nuclei of colorectal MC cells. (B) Loss of hMLH1. No immunoactivity of hMLH1 in nuclei of colorectal MC cells (magnification x 12.5).

Pathology Committee, and informed consent was obtained from all patients.

Patient age and gender, and tumor location and stage, were ascertained from the pathology report. All cases were staged using Turnbull's modification of Dukes' classification (9). Classifications of growth type were assessed by tumor edge morphology and invasive margin morphology. The former was classified as polypoid type when the tumor edge was obviously elevated above the level of the normal mucosa at the tumor margin (Fig. 1A) and as nonpolypoid type when the tumor edge was at the level or below the normal mucosa (Fig. 1B), using the criteria of George et al (10). The latter was classified as expanding type when the advancing front of the tumor was clearly demarcated and pushed the surrounding tissue, and as infiltrating type when the cancer cells spread into the surrounding tissue without a distinct border, using the criteria of Jass et al (11). We also graded MC for the extent of differentiation according to the WHO classification; welldifferentiated type was defined as glands lined by a columnar mucus-secreting epithelium together with intestinal mucin, and poorly differentiated type was defined as chains or irregular clusters of cells surrounded by mucus (1). The clinicopathologic features of the samples are summarized in Table I.
DNA extraction. Formalin-fixed, paraffin-embedded samples were cut serially at a thickness of $10 \mu \mathrm{m}$. Based on histopathological findings, the tumor and corresponding normal tissues were microdissected from each of five serial sections and the tissues were deparaffinized in xylene and rehydrated in a graded ethanol series. DNA was then extracted from the whole dissected tissue using a DNA Isolator PS Kit (Wako Pure Chemical, Osaka, Japan) according to the supplied protocol.

Screening of BRAF and $K$-ras mutation. The complete coding sequences of exon 11 ( $\mathrm{G}$ loop region) and 15 (activation segment) of $B R A F$ and exon 1 of K-ras were amplified using the polymerase chain reaction (PCR). The primer sequences were: for exon 11 of $B R A F$, forward 5'-GCT TGT CAC TTA TAA AGG AAA CTA-3', reverse 5'-TCC CTC TCA GGC ATA AGG TAA-3'; for exon 15 of $B R A F$, forward 5'-CCG GTT TTT AAA TTA GTC ACC T-3', reverse 5'-TCA TAA TGC TTG CTC TGA TAG GA-3'; and for exon 1 of K-ras, forward 5'-ACT GAA TAT AAA CTT GTG GTA G-3', reverse 5'-AGT TTC TTA CCA GGA CGT-3'. Direct sequencing of the amplified DNA was performed as follows. PCR products were purified using a QIAquick PCR Purification Kit (Qiagen, Tokyo, Japan), then sequenced on an ABI PRISM 
Table I. Clinicopathological features of the patients with mucinous carcinoma in the colorectum.

\begin{tabular}{lc}
\hline Gender & \\
Man & $30(69.8 \%)$ \\
Woman & $13(30.2 \%)$ \\
Age (year, mean \pm SD) & $64.2 \pm 13.6(29-90)$ \\
Tumor location & \\
Proximal & $24(55.8 \%)$ \\
Distal & $19(44.2 \%)$ \\
Dukes' stage & \\
A/B & $10(23.3 \%)$ \\
C/D & $33(76.7 \%)$ \\
Differentiation & \\
Well/moderate & $31(72.1 \%)$ \\
Poor/signet & $12(27.9 \%)$ \\
Tumor edge morphology & \\
Polypoid & $20(46.5 \%)$ \\
Nonpolypoid & $18(41.9 \%)$ \\
Unclassifiable & $5(11.6 \%)$ \\
Invasive margin morphology & \\
Expanding & \\
Infiltrating & $21(48.8 \%)$ \\
Mixed & $19(44.2 \%)$ \\
\hline
\end{tabular}

Proximal, from cecum to transverse colon; distal, from splenic flexure to rectum.

3700 DNA Analyzer (Applied Biosystems, Foster City, CA) using an ABI PRISM Big Dye Terminator Cycle Sequencing Kit (Applied Biosystems). The same primers were used for both amplification and sequencing. The resulting sequencing data were analyzed using Gene Scan Analysis Software (Applied Biosystems) in accordance with the manufacturer's protocol. All sequences were verified in both the forward and reverse directions.

Analysis of MSI. MSI was evaluated at five microsatellite markers (D5S346, BAT25, BAT26, D2S123 and D17S250) recommended by the National Cancer Institute panel (12). PCR was performed using fluorescent labeled multiplex primers. The amplified PCR products were analyzed using an ABI PRISM 310 Genetic Analyzer (Applied Biosystems) with Gene Scan Analysis Software provided by the manufacturer. If more than one microsatellite marker of tumor tissue exhibited differences from the patient's matched normal tissue, the tumor was classified as an MSI tumor.

Immunohistochemical analysis of hMLH1 and p53. Immunohistochemical staining for 553 or hMLH1 protein was carried out with an anti-human p53 antibody (NCL-p53-CM1; Novocastra Laboratories, Newcastle, UK; diluted 1:2000) or with an anti-human hMLH1 antibody (BD PharMingen, San Diego, CA; diluted 1:30) on formalin-fixed, paraffinembedded tissue sections using a Labeled Streptavidin-Biotin Kit (Dako Japan, Kyoto, Japan). For p53, positive controls
Table II. Relationship between $B R A F$ and K-ras mutation.

\begin{tabular}{lcc}
\hline & \multicolumn{2}{c}{ K-ras mutation } \\
\cline { 2 - 3 } & Positive & Negative \\
\hline$B R A F$ mutation & 0 & 4 \\
Positive & 13 & 26 \\
Negative & \\
\hline
\end{tabular}

and negative controls were used for each set of experiments. Sections of colorectal adenocarcinomas that had been confirmed to overexpress this protein were used as positive controls, and the antibody was not applied to negative controls. Immunoreactivity was considered positive if at least focal nuclear accumulation of $\mathrm{p} 53$ protein was detected. For hMLH1, negative tumor was determined when tumor cells showed no nuclear staining but the surrounding normal epithelial cells showed positive-nuclear staining (Fig. 2).

Statistics. The Chi-square test (Fisher's exact test when the expected number of any cell was $\leq 5$ cases) was performed to determine correlations among the various parameters. Cumulative survival rate was assessed by the Kaplan-Meier method and compared by log-rank test. Multivariate analysis was performed using the Cox proportional hazards model with hazard ratios (HR) and $95 \%$ confidence intervals $(\mathrm{CI})$ to evaluate independent prognostic factors. Survival was defined as the time from the date of surgery for colorectal MC to the date of death. Others deaths unrelated to colorectal MC were excluded for the purpose of survival analysis. Differences at $\mathrm{P}<0.05$ were considered to be statistically significant.

\section{Results}

$B R A F$ and $K$-ras mutation. BRAF mutation was detected in 4 (9.3\%) tumors, and in all cases was located at the hot spot codon 599 of exon 15. All BRAF mutations were $\mathrm{CTG} \rightarrow \mathrm{GAG}$ (V599E). K-ras mutation was detected in 13 (30.2\%) tumors, including $10(76.9 \%)$ at codon 12 and $3(23.1 \%)$ at codon 13 . The most frequent mutation at codon 12, GGT $\rightarrow$ GAT $($ G12D), was detected in 8 cases $(80 \%)$. All mutations at codon 13 were $\mathrm{GGC} \rightarrow \mathrm{GAC}(\mathrm{G} 13 \mathrm{D})$. Overall, 17 of $43 \mathrm{MCs}(39.5 \%)$ harbored mutations in either $B R A F$ or K-ras. No BRAF and $\mathrm{K}$-ras mutations were identified simultaneously in the same tumor (Table II).

Relationship of BRAF and K-ras mutation with clinicopathological features. The relationship of $B R A F$ and K-ras mutation with clinicopathological features is shown in Table III. We failed to detect any significant relationship of $B R A F$ and K-ras mutation with age, gender, tumor location, Dukes' stage or differentiation. With regard to classification by tumor edge morphology, 20 of $43 \mathrm{MCs}$ (46.5\%) were classified as polypoid type and $18(41.9 \%)$ were classified as nonpolypoid type. The remaining five were unclassifiable because one edge showed polypoid type and the other nonpolypoid type. All of $4 \mathrm{MCs}$ with $B R A F$ mutation and 9 of 13 MCs $(69.2 \%)$ with K-ras mutation were classified as polypoid type. MCs with $B R A F$ 
Table III. Relationship of BRAF and K-ras mutation with clinicopathological features.

\begin{tabular}{|c|c|c|c|c|}
\hline & $\begin{array}{l}B R A F(+) \\
(\mathrm{n}=4)(\%)\end{array}$ & $\begin{array}{l}\mathrm{K}-\operatorname{ras}(+) \\
(\mathrm{n}=13)(\%)\end{array}$ & $\begin{array}{c}B R A F(+) \text { or K-ras }(+) \\
(\mathrm{n}=17)(\%)\end{array}$ & $\begin{array}{c}B R A F(-) \text { and K-ras (-) } \\
(\mathrm{n}=26)(\%)\end{array}$ \\
\hline Age (year, mean $\pm \mathrm{SD}$ ) & $66.0 \pm 13.5$ & $67.2 \pm 14.7$ & $66.9 \pm 14.0$ & $61.8 \pm 13.3$ \\
\hline \multicolumn{5}{|l|}{ Gender } \\
\hline Man & $4(100)$ & $7(53.8)$ & $11(64.7)$ & $19(73.1)$ \\
\hline Woman & 0 & $6(46.2)$ & $6(35.3)$ & $7(26.9)$ \\
\hline \multicolumn{5}{|l|}{ Tumor location } \\
\hline Proximal & $3(75.0)$ & $7(53.8)$ & $10(58.8)$ & $14(53.9)$ \\
\hline Distal & $1(25.0)$ & $6(46.2)$ & $7(41.2)$ & $12(46.1)$ \\
\hline \multicolumn{5}{|l|}{ Dukes' stage } \\
\hline $\mathrm{A} / \mathrm{B}$ & $2(50.0)$ & $4(30.8)$ & $6(35.3)$ & $5(19.2)$ \\
\hline $\mathrm{C} / \mathrm{D}$ & $2(50.0)$ & $9(69.2)$ & $11(64.7)$ & $21(80.8)$ \\
\hline \multicolumn{5}{|l|}{ Differentiation } \\
\hline Well/moderate & $4(100)$ & $10(76.9)$ & $14(82.4)$ & $16(61.5)$ \\
\hline Poor/signet & 0 & $3(23.1)$ & $3(17.6)$ & $10(38.5)$ \\
\hline \multicolumn{5}{|l|}{ Tumor edge morphology } \\
\hline Polypoid & $4(100)$ & $9(69.2)$ & $13(76.5)$ & $8(30.8)$ \\
\hline Nonpolypoid & 0 & $3(23.1)$ & $3(17.6)$ & $14(53.8)$ \\
\hline Unclassifiable & 0 & $1(7.7)$ & $1(5.9)$ & $4(15.4)$ \\
\hline \multicolumn{5}{|c|}{ Invasive margin morphology } \\
\hline Expanding & $3(75.0)$ & $6(46.2)$ & $9(52.9)$ & $12(46.1)$ \\
\hline Infiltrating & $1(25.0)$ & $6(46.2)$ & $7(41.2)$ & $12(46.1)$ \\
\hline Mixed & 0 & $1(7.6)$ & $1(5.9)$ & $2(7.7)$ \\
\hline
\end{tabular}

$B R A F(+), B R A F$ mutation positive; K-ras (+), K-ras mutation positive.

Table IV. Relationship of BRAF and K-ras mutation with MSI and accumulation of p53 and hMLHI.

\begin{tabular}{|c|c|c|c|c|}
\hline & $\begin{array}{l}B R A F(+) \\
(\mathrm{n}=4)(\%)\end{array}$ & $\begin{array}{l}\mathrm{K}-\operatorname{ras}(+) \\
(\mathrm{n}=13)(\%)\end{array}$ & $\begin{array}{c}\text { BRAF }(+) \text { or K-ras }(+) \\
(\mathrm{n}=17)(\%)\end{array}$ & $\begin{array}{c}B R A F(-) \text { and K-ras }(-) \\
(\mathrm{n}=26)(\%)\end{array}$ \\
\hline \multicolumn{5}{|l|}{ MSI status } \\
\hline Instability & $2(50.0)$ & $1(7.7)$ & 3 (17.6) & $2(7.7)$ \\
\hline Stability & $2(50.0)$ & $12(92.3)$ & $14(82.4)$ & $24(92.3)$ \\
\hline \multicolumn{5}{|l|}{ p53 status } \\
\hline Positive & $1(25.0)$ & $4(30.8)$ & $5(29.4)$ & $10(38.5)$ \\
\hline Negative & $3(75.0)$ & $9(69.2)$ & $12(70.6)$ & $16(61.5)$ \\
\hline \multicolumn{5}{|c|}{ hMLHI status } \\
\hline Positive & $2(50.0)$ & $12(92.3)$ & $14(82.4)$ & $24(92.3)$ \\
\hline Negative & $2(50.0)$ & $1(7.7)$ & $3(17.6)$ & $2(7.7)$ \\
\hline
\end{tabular}

$B R A F(+), B R A F$ mutation positive; K-ras (+), K-ras mutation positive.

mutation showed polypoid type more frequently than those without $B R A F$ or K-ras mutation $(100 \%$ vs. $30.8 \%, \mathrm{P}=0.033)$. Similarly, although the difference was not statistically significant, MCs with K-ras mutation showed polypoid type more frequently than those without $B R A F$ or K-ras mutation (69.2\% vs. $30.8 \%, \mathrm{P}=0.071)$. On the other hand, we failed to detect any significant relationship of these mutations with invasive margin morphology.

Relationship of BRAF and K-ras mutation with MSI status, expression of p53 and hMLH1. The relationship of BRAF and $\mathrm{K}$-ras mutation with MSI, p53 and hMLH1 status is shown in 
Table IV. MSI and loss of hMLH1 were detected in 5 of 43 MCs (11.6\%). The incidences of MSI and loss of hMLH1 occurred in 2 of 4 MCs $(50.0 \%)$ with BRAF mutation, compared with 1 of $13(7.7 \%)$ with K-ras mutation, and 2 of $26(7.7 \%)$ without $B R A F$ or K-ras mutation. The incidences of MSI and loss of hMLH1 tended to be higher in $B R A F$ mutated $\mathrm{MC}$ than in non-BRAF mutated MC (50\% vs. $8.3 \%$, $\mathrm{P}=0.060)$. Expression of p53 was detected in 15 of $43 \mathrm{MCs}$ $(34.9 \%)$. There was no significant relationship of $B R A F$ and $\mathrm{K}$-ras mutation with p53 expression.

Survival analysis. Log-rank statistics showed that BRAF and $\mathrm{K}$-ras mutation was not associated with patient prognosis, whereas tumor edge morphology and invasive margin morphology were found to affect patient prognosis. In terms of tumor edge morphology, nonpolypoid type had a closer association with poor patient prognosis than polyoid type $(\mathrm{P}=0.016)$. In terms of invasive margin morphology, infiltrating type had a closer association with poor patient prognosis than expanding type $(\mathrm{P}=0.006)$.

Multivariate analysis using Cox regression and correcting for gender and age at surgery, Dukes' stage (A/B or C/D) and differentiation (well/moderate or poor/signet) showed that tumor edge morphology and invasive margin morphology were independent prognostic factors [HR 3.3 (95\% CI 1.29.3); $\mathrm{P}=0.028$ and HR 6.4 (95\% CI 1.8-22.7); $\mathrm{P}=0.026$, respectively]. Dukes' stage and differentiation were also shown to significantly affect patient prognosis [HR 4.1 (95\% CI 1.116.1); $\mathrm{P}=0.014$ and HR 4.4 (95\% CI 1.6-12.3); $\mathrm{P}=0.005$, respectively].

\section{Discussion}

In this study, we examined the incidence of $B R A F$ mutation in colorectal $\mathrm{MC}$, and clarified the relationship of $B R A F$ mutation with other genetic alterations and clinicopathological features. BRAF mutation was observed in $9.3 \%$ of colorectal MCs and in all cases was located at the hot spot codon 599 of exon 15. BRAF mutation in all these cases was $\mathrm{CTG} \rightarrow \mathrm{GAG}$, resulting in the substitution of valine $(\mathrm{V})$ by glutamic acid (E). The incidence of BRAF mutation was similar to that reported previously in colorectal carcinoma. K-ras mutation was observed in $30.2 \%$ of colorectal MCs, being at codon 12 in $76.9 \%$ and codon 13 in $23.1 \%$. These results suggest that $B R A F$ mutation would play an important role in the tumorigenesis of colorectal MC, similar to K-ras mutation.

Both BRAF and K-ras are members of the Ras/Raf/MEK/ MAP kinase cascade, which transduces various growth signals from the cell surface to the nucleus. As in previous studies, we found no colorectal MC that concurrently contained both $B R A F$ mutation at codon 599 of exon 15 and K-ras mutation $(13,14)$. The combined incidence of $B R A F$ and K-ras mutation was approximately $40 \%$ in colorectal MC, suggesting that activation at various points of the Ras/Raf/MEK/MAP kinase cascade would constitute a key event in the tumorigenesis of colorectal MC.

Approximately $15 \%$ of sporadic colorectal carcinomas show MSI, and the majority of those with MSI demonstrate inactivation of the MMR gene due to hypermethylation of the hMLH1 gene (15-17). Recent data have shown that BRAF mutation is associated with a high frequency of MSI and inactivation of the MMR gene in colorectal carcinoma (14). Lubomierski et al reported that the incidence of $B R A F$ mutation was approximately five times $(27 \%$ vs. $5 \%)$ higher in MSI tumors than in non-MSI tumors (18). In this study, although the number of MCs examined was not large enough to allow definite statistical correlations, the incidences of MSI and loss of hMLH1 tended to be higher in BRAF mutated MC than in non-BRAF mutated MC (50\% vs. $8.3 \%, \mathrm{P}=0.060)$. These results were nearly consistent with those of previous studies of colorectal carcinoma $(14,19)$.

In histological configuration of colorectal carcinomas, there are two distinct subtypes: protrusive and flat carcinomas. These may represent different pathways of colorectal tumorigenesis. Shimoda et al classified the growth of early colorectal carcinoma into two types, polypoid and nonpolypoid, on the basis of tumor edge morphology, and suggested that polypoid carcinomas would develop from adenomatous polyps whereas nonpolypoid carcinomas would develop from flat polyps or de novo in nonadenomatous mucosa (20). In addition, a number of mutational data have supported the contention that polypoid and nonpolypoid tumors are separate entities, because the incidences of K-ras and APC gene mutation in nonpolypoid tumors is lower than that in polypoid tumors (21-25). In advanced colorectal carcinoma, George et al likewise classified growth type and reported that K-ras mutation was more frequent in polypoid carcinomas than in nonpolypoid carcinomas, and that the latter were significantly more aggressive than the former (10). In this study, we focused on the relationship between histological configuration and several genetic alterations including $B R A F$ mutation in colorectal MC, using this morphological classification.

We found that $46.5 \%$ of the classifiable carcinomas were polypoid and that $41.9 \%$ were nonpolypoid roughly, thus showing roughly the same incidence. All of $4 \mathrm{MCs}$ with $B R A F$ mutation and 9 of $13 \mathrm{MCs}$ with K-ras mutation were classified as polypoid type. The incidence of polypoid MC with $B R A F$ mutation was higher than that without $B R A F$ or K-ras mutation ( $100 \%$ vs. $30.8 \%, \mathrm{P}=0.033$ ), and the incidence of polypoid $\mathrm{MC}$ with K-ras mutation also tended to be higher than that without $B R A F$ or $\mathrm{K}$-ras mutation $(69.2 \%$ vs. $30.8 \%, \mathrm{P}=0.071)$. Similar to K-ras mutation, $B R A F$ mutation was also associated with polypoid carcinomas. This result suggests that activation of the MAP kinase cascade by BRAF or K-ras mutation would be associated with polypoid carcinomas, and that polypoid and nonpolypoid MC may develop through distinct pathways. On the other hand, differentiation according to the WHO definition and invasive margin morphology, which was one of the prognostic factors classified by Jass et al (11), were not associated with $B R A F$ or $\mathrm{K}$-ras mutation. Thus, it is conceivable that, in colorectal $\mathrm{MC}, B R A F$ and $\mathrm{K}$-ras mutation may play an important role in tumor edge morphology, but not in differentiation and tumor invasion morphology.

Many studies have reported that genetic alterations affect the prognosis of patients with carcinoma. It has been reported that K-ras mutation seems to be associated with poor prognosis in colorectal carcinoma (26-28). However, conflicting results have also been reported (29-31). In addition no studies have investigated the association between $B R A F$ mutation and the prognosis of patients with colorectal carcinoma. In this study, 
we investigated whether activation of the MAP kinase cascade by $B R A F$ and $\mathrm{K}$-ras mutation influences the prognosis of patients with colorectal MC. We also investigated the association between growth pattern and prognosis. Our data showed that activation of the MAP kinase cascade did not affect the prognosis of patients with colorectal MC, whereas tumor edge morphology and invasive margin morphology have an effect. As reported previously, nonpolypoid and infiltrating types were significantly more aggressive than polypoid and expanding types in colorectal carcinoma. These data suggest that tumor morphology rather than genetic alterations would predict poor prognosis in patients with colorectal MC. In this study, however, due to the small sample size, it was not possible to determine the actual prognostic value of $B R A F$ or K-ras in colorectal MC. Further studies using a large number of cases will be necessary to clarify the effect of these mutations on the prognosis of patients with colorectal MC.

\section{Acknowledgements}

The authors thank MS A. Shimizu, T. Otsuki and C. Matsuyama (Department of Surgical and Molecular Pathology, Dokkyo University School of Medicine, Tochigi, Japan) for their technical assistance.

\section{References}

1. Jass JR and Sobin LH: Histological typing of intestinal tumors. In: Large Intestine: Epithelial Tumours. Springer-Verlag, Berlin, pp32-33, 1989.

2. Symonds DA and Vickery AL: Mucinous carcinoma of the colon and rectum. Cancer 37: 1891-1900, 1967.

3. Nozoe T, Anai H, Nasu S and Sugimachi K: Clinicopathological characteristics of mucinous carcinoma of the colon and rectum. J Surg Oncol 75: 103-107, 2000.

4. Fearon ER and Vogelstein B: A genetic model for colorectal tumorigenesis. Cell 61: 759-767, 1990.

5. Vogelstein B, Fearon ER, Hamilton SR, Kern SE, Preisinger AC, Leppert M, Nakamura Y, White R, Smits AM and Bos JL: Genetic alterations during colorectal-tumor development. N Engl J Med 319: 525-532, 1988.

6. Maltzman T, Knoll K, Martinez ME, Byers T, Stevens BR, Marshall JR, Reid ME, Einspahr J, Hart N, Bhattacharyya AK, Kramer CB, Sampliner R, Alberts DS and Ahnen DJ: Ki-ras proto-oncogene mutations in sporadic colorectal adenomas: relationship to histologic and clinical characteristics. Gastroenterology 121: 302-309, 2001.

7. Peyssonnaux $\mathrm{C}$ and Eychene A: The raf/MEKERK pathway: new concepts of activation. Bio Cell 93: 53-62, 2001.

8. Davies H, Bignell GR, Cox C, Stephens P, Edkins S, Clegg S, Teague J, Woffendin H, Garnett MJ, Bottomley W, Davis N, Dicks E, Ewing R, Floyd Y, Gray K, Hall S, Hawes R, Hughes J, Kosmidou V, Menzies A, Mould C, Parker A, Stevens C, Watt S, Hooper S, Wilson R, Jayatilake H, Gusterson BA, Cooper C, Shipley J, Hargrave D, Pritchard-Jones K, Maitland N, Chenevix-Trench G, Riggins GJ, Bigner DD, Palmieri G, Cossu A, Flanagan A, Nicholson A, Ho JW, Leung SY, Yuen ST, Weber BL, Seigler HF, Darrow TL, Paterson H, Marais R, Marshall CJ, Wooster R, Stratton MR and Futreal PA: Mutations of the BRAF gene in human cancer. Nature 417: 949-954, 2002.

9. Turnbull RB Jr, Kyle K, Watson FR and Spratt J: Cancer of the colon: the influence of the no-touch isolation technic on survival rates. Ann Surg 166: 420-427, 1967.

10. George SM, Makinen MJ, Jernvall P, Makela J, Vihko P and Karttunen TJ: Classification of advanced colorectal carcinomas by tumor edge morphology: evidence for different pathogenesis and significance of polypoid and nonpolypoid tumors. Cancer 89: 1901-1909, 2000.

11. Jass JR, Love SB and Northover JM: A new prognostic classification of rectal cancer. Lancet 1: 1303-1306, 1987.
12. Boland CR, Thibodeau SN, Hamilton SR, Sidransky D, Eshleman JR, Burt RW, Meltzer SJ, Rodriguez-Bigas MA, Fodde R, Ranzani GN and Srivastava S: A National Cancer Institute workshop on microsatellite instability for cancer detection and familial predisposition: development of international criteria for the determination of microsatellite instability in colorectal cancer. Cancer Res 58: 5248-5257, 1998.

13. Yuen ST, Davies H, Chan TL, Ho JW, Bignell GR, Cox C, Stephens P, Edkins S, Tsui WW, Chan AS, Futreal PA, Stratton MR, Wooster R and Leung SY: Similarity of the phenotypic patterns associated with BRAF and KRAS mutations in colorectal neoplasia. Cancer Res 62: 6451-6455, 2002.

14. Rajagopalan H, Bardelli A, Lengauer C, Kinzler KW, Vogelstein B and Velculescu VE: Tumorigenesis: RAF/RAS oncogenes and mismatch-repair status. Nature 418: 934, 2002.

15. Kane MF, Loda M, Gaida GM, Lipman J, Mishra R, Goldman H, Jessup JM and Kolodner R: Methylation of the hMLH1 promoter correlates with lack of expression of hMLH1 in sporadic colon tumors and mismatch repair-defective human tumor cell lines. Cancer Res 57: 808-811, 1997.

16. Cunningham JM, Christensen ER, Tester DJ, Kim CY, Roche PC, Burgart LJ and Thibodeau SN: Hypermethylation of the hMLH1 promoter in colon cancer with microsatellite instability. Cancer Res 58: 3455-3460, 1998.

17. Jeong SY, Shin KH, Shin JH, Ku JL, Shin YK, Park SY, Kim WH and Park JG: Microsatellite instability and mutations in DNA mismatch repair genes in sporadic colorectal cancers. Dis Colon Rectum 46: 1069-1077, 2003.

18. Lubomierski N, Plotz G, Wormek M, Engels K, Kriener S, Trojan J, Jungling B, Zeuzem S and Raedle J: BRAF mutations in colorectal carcinoma suggest two entities of microsatelliteunstable tumors. Cancer 104: 952-961, 2005.

19. Wang L, Cunningham JM, Winters JL, Guenther JC, French AJ, Boardman LA, Burgart LJ, McDonnell SK, Schaid DJ and Thibodeau SN: BRAF mutations in colon cancer are not likely attributable to defective DNA mismatch repair. Cancer Res 63: 5209-5212, 2003

20. Shimoda T, Ikegami M, Fujisaki J, Matsui T, Aizawa S and Ishikawa E: Early colorectal carcinoma with special reference to its development de novo. Cancer 64: 1138-1146, 1989.

21. Fujimori T, Satonaka K, Yamamura-Idei Y, Nagasako K and Maeda S: Non-involvement of ras mutations in flat colorectal adenomas and carcinomas. Int J Cancer 57: 51-55, 1994.

22. Yukawa M, Fujimori T, Maeda S, Tabuchi M and Nagasako K: Comparative clinicopathological and immunohistochemical study of ras and p53 in flat and polypoid type colorectal tumors. Gut 35: 1258-1261, 1994 .

23. Chiang JM, Chou YH and Chou TB: K-ras codon 12 mutation determines the polypoid growth of colorectal cancer. Cancer Res 58: 3289-3293, 1998 .

24. Higashidani Y, Tamura S, Morita T, Tadokoro T, Yokoyama Y, Miyazaki J, Yang Y, Takeuchi S, Taguchi H and Onishi S: Analysis of K-ras codon 12 mutation in flat and nodular variants of serrated adenoma in the colon. Dis Colon Rectum 46: 327-332, 2003.

25. Kaneko K, Kurahashi T, Makino R, Konishi K, Ito H, Katagiri A, Kumekawa Y, Hirayama Y, Yoneyama K, Kushima M, Kusano M, Tajiri H, Rembacken BJ, Mitamura K and Imawari M: Pathological features and genetic alterations in colorectal carcinomas with characteristics of nonpolypoid growth. Br J Cancer 91: 312-318, 2004.

26. Font A, Abad A, Monzo M, Sanchez JJ, Guillot M, Manzano JL, Pinol M, Ojanguren I and Rosell R: Prognostic value of K-ras mutations and allelic imbalance on chromosome $18 \mathrm{q}$ in patients with resected colorectal cancer. Dis Colon Rectum 44: 549-557, 2001.

27. Andreyev HJ, Norman AR, Cunningham D, Oates J, Dix BR, Iacopetta BJ, Young J, Walsh T, Ward R, Hawkins N, Beranek M, Jandik P, Benamouzig R, Jullian E, Laurent-Puig P, Olschwang S, Muller O, Hoffmann I, Rabes HM, Zietz C, Troungos C, Valavanis C, Yuen ST, Ho JW, Croke CT, O'Donoghue DP, Giaretti W, Rapallo A, Russo A, Bazan V, Tanaka M, Omura K, Azuma T, Ohkusa T, Fujimori T, Ono Y, Pauly M, Faber C, Glaesener R, de Goeij AF, Arends JW, Andersen SN, Lovig T, Breivik J, Gaudernack G, Clausen OP, De Angelis PD, Meling GI, Rognum TO, Smith R, Goh HS, Font A, Rosell R, Sun XF, Zhang H, Benhattar J, Losi L, Lee JQ, Wang ST, Clarke PA, Bell S, Quirke P, Bubb VJ, Piris J, Cruickshank NR, Morton D, Fox JC, Al-Mulla F, Lees N, Hall CN, Snary D, Wilkinson K, Dillon D, Costa J, Pricolo VE, Finkelstein SD, Thebo JS, Senagore AJ, Halter SA, Wadler S, Malik S, Krtolica K and Urosevic N: Kirsten ras mutations in patients with colorectal cancer: the "RASCAL II" study. Br J Cancer 85: 692-696, 2001. 
28. Conlin A, Smith G, Carey FA, Wolf CR and Steele RJ: The prognostic significance of K-ras, p53, and APC mutations in colorectal carcinoma. Gut 54: 1283-1286, 2005.

29. Pricolo VE, Finkelstein SD, Wu TT, Keller G, Bakker A, Swalsky PA and Bland KI: Prognostic value of TP53 and K-ras-2 mutational analysis in stage III carcinoma of the colon. Am J Surg 171: 41-46, 1996.
30. Bleeker WA, Hayes VM, Karrenbeld A, Hofstra RM, Verlind E, Hermans J, Poppema S, Buys CH and Plukker JT: Prognostic significance of K-ras and TP53 mutations in the role of adjuvant chemotherapy on survival in patients with Dukes $\mathrm{C}$ colon cancer. Dis Colon Rectum 44: 358-363, 2001.

31. Chang SC, Lin JK, Yang SH Wang HS, Li AF and Chi CW: Relationship between genetic alterations and prognosis in sporadic colorectal cancer. Int J Cancer 118: 1721-1727, 2006. 